\title{
Role of Plankton in Aquaculture
}

\author{
J. Yaswanth Kumar ${ }^{1 *}$, S. Janardana Reddy ${ }^{1}$ and T. Suguna ${ }^{2}$ \\ ${ }^{1}$ Department of Fishery Science and Aquaculture, SVU College of Sciences, Sri Venkateswara \\ University, Tirupati, Andhra Pradesh, India \\ ${ }^{2}$ Fisheries Research Station, Sri Venkateswara Veterinary University, Undi, West Godavari \\ (dist), Andhra Pradesh, India \\ *Corresponding author
}

\section{A B S T R A C T}

\section{Keywords}

Phytoplankton, Zooplankton, Season, Productivity and semi intensive culture

Article Info

Accepted:

18 August 2020 Available Online: 10 September 2020
A study on the seasonal changes in the plankton community was carried out in semi intensive carp culture ponds over a period of 9 months. Plankton diversity and physicochemical parameters of water are important criteria for evaluating the suitability of water for culture practices. Among phytoplankton the population of Chlorophyceae was maximum $(42.60 \%)$ and among zooplankton rotifers $(43.86 \%)$ are dominated followed by copepods. The highest phytoplankton and zooplankton abundance was observed in summer and the lowest was in winter. Phytoplankton and zooplankton are positively correlated (r: 0.713) to each other in semi intensive culture pond.

\section{Introduction}

Aquaculture organisms have to obtain all their nutritional requirements, except for part of the mineral requirements, through the food they consume. In nature, most of the organisms subsist on live food consisting of plants and animals obtained from the environment, but some do ingest and possible utilize detritus along with associated organisms. The initial source of food for many larval organisms is phytoplankton. This is probably associated with the size of the larvae at hatching. After a certain period of time the larvae of most species can be fed exclusively on zooplankton or a combination of plant and animal matter i.e. plankton. The term 'plankton' can be defined chiefly as microscopic drifting or floating organisms in the sea and fresh waters and may be having feasible floating devices. The plant components of all the plankton are the phytoplankton and are the primary producers for the entire aquatic body, whereas the animal components of the plankton are the zooplankton and are the primary consumers. 
Planktons are very sensitive to the environment they live in and any alteration in the environment leads to the changes in the plankton communities in terms of tolerance abundance, diversity and dominance in the habitat (Mathivonam, 2007). The density and diversity of the plankton are greatly influenced by the different physicochemical parameters of water (Wetzel, 1975). Species composition of the plankton community is an efficient indicator of water quality. Many biotic and abiotic processes contribute to variability in plankton diversity in aquatic ecosystems. Seasonal requirement of plankton assemblages are closely linked to seasonal changes in temperature, external hydraulic, nutrient loads and light availability (Malten et al., 1991), other process acting on as time periods on days to week, like meteorological and hydrological events (Guillermo, 2009) and also pollution stress on them (Raja et al., 2008).

The abundance of planktonic organisms in a water body influences the feeding regime of fish. In fish farm operations, lack of suitable food is believed to be the main source of mortality of early larval and fry stages of fish. Such mortalities can be greatly reduced, if not completely prevented by provision of adequate amounts of natural food (plankton). Zooplankton are very important in the food web of open-water ecosystems, in both marine and freshwaters (Ekelemu, 2010). Zooplankton is eaten by relatively small fish (planktivores), which are then eaten by larger fishes. Thus the zooplankton is an important link in the transfer of energy from the algae (primary producers) to the entire ecological and economic fish community (consumers). Most zooplankton are secondary consumers, that is, they are herbivores that graze on phytoplankton (unicellular or colonial algae) suspended in the water column. This study provides basic and crucial information to students, academicians and aqua farmers regarding the qualitative, quantitative varieties and their role in aquaculture.

\section{Materials and Methods}

Plankton was collected from surface water by plankton net and sample was fixed in 5\% formaldehyde and Lugol's solution for zooplankton and phytoplankton respectively. The plankton samples were stored in plastic bottles and observed under compound microscope for identification. The plankton and algae were identified with the help of various keys e.g. Needham (1962), Cramar (1984), Plaskitt (1997), Sinha and Naik (1997) and APHA (1989). Quantitative analysis of plankton was done by Sedgwick Rafter cell. Qualitatively analysed by species wise. The physicochemical parameters such as temperature, transparency, $\mathrm{pH}$, free carbon dioxide $\left(\mathrm{CO}_{2}\right)$, dissolve oxygen (DO), alkalinity and hardness were measured during the study period (Table 2).

\section{Results and Discussion}

In general, the farmers understand that the presence of natural feeds in the ponds especially the presence of good quality phytoplankton, contributes significantly to the growth of their stock, and often comment that FCR increase in those ponds that do not maintain optimal levels of phytoplankton. Estimation of plankton was done and observations were recorded at fortnightly intervals which are presented in Table 1. The phytoplankton population mainly consisted of Chlorophyceae, Cyanophyceae, Bacillariophyceae, Euglenophyceae and others like Dinophyceae, Chrysophyceae and Xanthophyceae. Zooplankton was represented by Rotifera, Cladocera and Copepods. Among the plankton Rotifer was dominated and followed by Copepods and Cladocerans. In the Rotifera five genera and nine species were observed. Among the Rotifera genus 
Brachions is the dominant group. The zooplankton consisted mainly of Rotifers and Copepods followed by Cladocerans and

Protozoans. Population density of zooplankton was always less than phytoplankton.

Table.1 Percentage contribution of various types of plankton

\begin{tabular}{|l|c|}
\hline \multicolumn{2}{|c|}{ Plankton Avg. population } \\
\hline Phytoplankton (\%) \\
\hline Chlorophyceae & 42.60 \\
\hline Cyanophyceae & 20.30 \\
\hline Euglenophyceae & 13.10 \\
\hline Bacillariophyceae & 15.80 \\
\hline Others & $\mathbf{8 . 2 0}$ \\
\hline Zooplankton (\%) & \\
\hline Rotifers & 43.86 \\
\hline Copepods & 37.90 \\
\hline Others & 18.24 \\
\hline
\end{tabular}

Table.2 Physico chemical water quality parameters

\begin{tabular}{|c|c|c|}
\hline Parameter & Minimum & Maximum \\
\hline Temperature & $22.5^{\mathrm{O}} \mathrm{C}$ & $34^{\mathrm{O}} \mathrm{C}$ \\
\hline pH & 6.9 & 8.2 \\
\hline Transparency (cm) & 24 & 30 \\
\hline Dissolved oxygen (mg/lt) & 5.50 & 6.90 \\
\hline $\mathbf{C O}_{\mathbf{2}}$ (mg/lt) & 1.00 & 1.25 \\
\hline Alkalinity (mg/lt) & 175 & 250 \\
\hline Hardness (mg/lt) & 140 & 230 \\
\hline
\end{tabular}

Phytoplankton ranged from 126 to 654 organisms litre ${ }^{-1}$ and zooplankton ranged between 102 to 484 organisms litre $^{-1}$ in culture pond. Peak plankton production was achieved in April and May and the lowest in December. Phytoplankton and zooplankton are positively correlated (r: 0.713) to each other in culture pond. Among phytoplankton the population of Chlorophyceae was maximum $42.60 \%$. Rotifers dominated in pond followed by copepods as shown in Table 1.

In the aquatic ecosystem plankton play a critical role not only in converting plant food to animal food but also serves as source of food for their organisms (Rajashekhar et al., 2010). The present study indicated that a total of 16 zooplankton species were recorded in the study pond comprising of 9 Rotifera, 3 Cladocera and 4 Copepods.

The present studies were found with higher $\mathrm{pH}$ values and decreased $\mathrm{CO}_{2}$ values i.e. negative correlation was found between $\mathrm{pH}$ and $\mathrm{CO}_{2}$. $\mathrm{pH}$ is significantly correlated with phytoplankton and dissolved oxygen within treatment. Dissolved oxygen is significantly correlated with both phytoplankton (r: 0.149) and zooplankton (r: 0.073). In the present study, negative correlation was observed between phytoplankton and Free $\mathrm{CO}_{2}$. Chari (1983) also found non-significant negative correlation between phytoplankton and free $\mathrm{CO}_{2}$ and explained that free $\mathrm{CO}_{2}$ may not be a 
controlling factor for phytoplankton production as they have the ability to obtain $\mathrm{CO}_{2}$ from bicarbonates. Alkalinity is positively correlated with phytoplankton population in the present study.

Phytoplankton and zooplankton and other natural food organisms significantly contribute to the nutrition of the fish. Plankton is the natural feed for aquatic organisms. They enhance the immunity of the aquatic organisms (shell fish and fin fish). The water quality of the aquatic ponds is highly influenced by the plankton existence.

They regulate transparency, dissolved oxygen, temperature and decreasing accumulation of $\mathrm{CO}_{2}, \mathrm{NH}_{3}, \mathrm{NO}_{2}$ and $\mathrm{H}_{2} \mathrm{~S}$ in water. Even $\mathrm{NH}_{4}^{+}$ and heavy metals are also highly influenced by their existence. Thus the pond water quality will be sterilized by lowering the content of toxic compounds. The existence of plankton in aqua ponds lessens the cost of production, especially in the feed investment, almost to half the amount of investment is lessened.

Hence the aqua farmers regularly monitor the existence of plankton in aquatic ponds as they play a key role in survival, growth, cost of production and potentiality of the water body.

\section{References}

APHA. 1989. Standard methods for the examination of water and waste water $17^{\text {th }}$ Ed., American water works association, Am. Public health assoc., and Washington, D.C. pp: 1193.

Chari, M.S.1983. Toxicity of chemical pollutants to a fresh water telost, Channa punctatus Bloach. Ph. D.Thesis. Aligarh
Muslim University, Aligarh. (U.P.), India. $1-140 \mathrm{p}$.

Cramer, J.1984. Algae of the Indian subcontinent. Inder A.R. Ganter Verlag Kanmandit, gerellschaft.: 1- 445.

Ekelemu, J.K. (2010) A survey of the zooplankton community of On a Lake, Southern Nigeria. International Journal of Agricultural and Rural Research. IJARD. 1(2): 185- 190.

Guillermo, C. 2009. The use of phytoplankton patterns of diversity for algal bloom management. Limnologica, 39: 225- 227.

Malten, M.A., Paeel, H.W., Rudek, J. 1991. Seasonal phytoplankton composition, productive and biomass in the Neuse River Estuary, North Carolina. Estur. Coast. Shelf. Sci., 32: 609-623.

Mathivonam, V.P., Vijayan, S., Sabhanayakan and Jayachitra, O. 2007. An assessment of plankton population of Cauvery River with reference to population. J. Env. Biol., 28: 523-526.

Nedham, G.J. and Needham, P.R. 1962. A guide to the study of fresh water biology. Holden-Day Inc. Sanfrancisco, Constable and co. Ltd. London. pp1-106.

Plaskit, F.J.W. 1997. Microscopic Freshwater algae. Biotech books Delhi- 11003. pp. 1278.

Raja, P., Amaranath, A.M., Elangovan, V. and Palanivel, M. 2008. Evaluation of physical and chemical parameters of river Kaveri, Tiruchirapalli Tamil Nadu, India. J. Env. Biol. 29: 765-768.

Sinha, S. and Naik, M.L. 1997. Phytoplankton and Macrophytes in the ponds of Raipur city area. Pt. Ravishankar Shukala, University. Raipur. 1-163 p.

Wetzel, R.G. 1975. Limnology, W.B. Sauders CO: Philadelphia pp. 743.

\section{How to cite this article:}

Yaswanth Kumar, J., S. Janardana Reddy and Suguna, T. 2020. Role of Plankton in Aquaculture. Int.J.Curr.Microbiol.App.Sci. 9(09): 2848-2851. doi: https://doi.org/10.20546/ijcmas.2020.909.351 